\title{
Narracje wolnościowe w niemieckiej literaturze po 1945 roku
}

Freedom narratives in German literature after 1945. The article aims to indicate what freedom models have been created in post-1945 German literature. What seems particularly interesting is looking into the development of literary motifs in correlation with political events and social movements. The articles refer to such significant milestones as 1945, 1968, 1989, 2011, and finally, 2015. Theses surrounding the theories of contemporariness and modernization are key to those thoughtful considerations. The processes of individualization and hybridization occurring within one world experiencing globalization are also important.

Keywords: contemporary German literature, freedom, globalization, migration

Co do mnie, nazywam wolną taką rzecz, która istnieje i działa wyłącznie na mocy konieczności swojej własnej natury, natomiast przymuszoną nazywam taką, która ze strony jakiejś innej podlega determinacji do istnienia i do działania w pewien określony sposób. [...] Widzisz zatem, że zasadzam wolność nie na swobodnym postanowieniu, ale na swobodnej konieczności ${ }^{1}$.

Sztuka jest córką wolności².

* Adres do korespondencji: Instytut Filologii Germańskiej, pl. Nankiera 15b, 50-140 Wrocław. E-mail: monika.wolting@uwr.edu.pl.

${ }^{1}$ B. de Spinoza, „List LVIII — Spinoza do Schullera” [październik 1674], [w:] Listy mężów uczonych do Benedykta de Spinozy oraz odpowiedzi autora wielce pomocne dla wyjaśnienia jego dzieł, Warszawa 1961, s. 261.

2 F. Schiller, „Über die ästhetische Erziehung des Menschen in einer Reihe von Briefen”, [w:] idem, Sämtliche Werke, t. 5. Erzählungen. Theoretische Schriften, Darmstadt 1981, s. 572.

Miscellanea Posttotalitariana Wratislaviensia 8, 2020

(C) for this edition by CNS 
Człowiek dąży do wolności. Jeżeli istnieją jakiekolwiek wartości wspólne dla ludzi społeczeństw Zachodu, to prawdopodobnie są to indywidualność, wolność i samostanowienie. Praca niemieckich myślicieli, a później intelektualistów nad do dzisiaj niedokończonym projektem Indywidualnej Wolności zapoczątkowana została rozważaniami Immanuela Kanta w kontekście przemyśleń Thomasa Hobbesa.

Kant przyjmuje w swoich tezach, że istnieją prawa moralne, które bez względu na pobudki empiryczne, to jest na szczęśliwość lub korzyść, określają całkowicie a priori działanie lub zaniechanie, czyli używanie wolności przez istotę rozumną w ogóle, i że te prawa nakazują w sposób bezwzględny (a nie jedynie hipotetyczny) i są pod każdym względem konieczne. Na tej podstawie formułuje naczelne prawo moralne w kształcie imperatywu kategorycznego: „Postępuj tak, aby maksyma twojej woli zawsze mogła mieć zarazem ważność jako pryncypium prawodawstwa powszechnego"3. Kant zareagował swoimi przemyśleniami na koncepcję wolności Thomasa Hobbesa (1588-1679), który rozumiał ją jako dowolność: każdy, kto swoim działaniem nie przeszkadza innym, jest wolny. Immanuel Kant (1724-1804) uważał takie rozumowanie za niewystarczające, zakładał bowiem, że wolność człowieka może być ograniczona nie tylko z zewnątrz, przez innych, ale także od wewnątrz, przez niego samego. I tak postrzega Kant wolność - nie tylko jako swobodę arbitralną, lecz także jako autonomię lub samoregulację. Najwyższą formą wolności jest działanie zgodnie z zasadami, które są prawem ogólnym. Słynny termin Kanta na to: „imperatyw kategoryczny”, łączący wolność, rozum i moralność.

Sztywne wzorce arbitralne stawały się z czasem coraz mniej wiążące zarówno dla indywiduum, jak i dla literatury. Należy bowiem wyjść z założenia, że literatura reaguje żywo na przemiany społeczne, wprowadza nowe wzorce i treści do światów fikcjonalnych. Wolność stała się centralnym tematem literatury pooświeceniowej i nie zatraciła do dziś na swej sile czy atrakcyjności. Modernizacja literatury przebiega na poziomie podejmowania nowych tematów oraz przejawia się w nowych formach literackich. Literatura wciąż tworzy nowe figury, poszukuje nowych możliwości wyrazu, tworzy swoje odrębne, nowatorskie style i formuły. Wolność we wszystkich odsłonach staje się tematem pooświeceniowej literatury niemieckojęzycznej: na poziomie formy, z którą autorzy coraz więcej eksperymentują, na poziomie akcji, w której figury wymagają od swojego otoczenia prawa do wolności i próbują się z tą czasami trudną wolnością zmierzyć. Historia literatury niemieckiej jest historią poszukiwań wolności.

Współczesne rozumienie samostanowienia, które kształtuje współczesną kulturę, przez ostatnie stulecia podlegało modyfikacjom. Współczesny człowiek nie ma na celu jedynie przeciwdziałania zewnętrznym ograniczeniom lub racjonalnej samoregulacji, ale zwraca się ku indywidualistycznej koncepcji postrzegania wolności jako samorealizacji. Głównym elementem tak rozumianej wolności jest przypuszczenie, że może jej zagrozić konformizm społeczny (John Stuart Mill, 1806-1873).

3 I. Kant, Krytyka praktycznego rozumu, przeł. J. Gałecki, Warszawa 1972, s. 58. 
Imperatyw kategoryczny Kanta jest niewiążący, choć obecny, gdyż wciąż stanowi pole odwoławcze.

Pierwsze lata po nazistowskiej katastrofie były dla niemieckich pisarzy i intelektualistów okresem poszukiwań i prób odbudowy kulturowej tożsamości. Głównymi celami ich zaangażowania były pokonanie następstw narodowego socjalizmu, ukazywanie stanu duchowego społeczeństwa oraz tworzenie nowej estetycznej wrażliwości. Oświeceniowa koncepcja wolności, towarzysząca kulturze niemieckiej począwszy od epoki oświecenia, okazała się dla społeczeństwa niemieckiego w pierwszej połowie XX wieku niezdolna do wypracowania społecznego modelu zgodnego z jej przesłankami. Proklamowany przez narodowych socjalistów powrót do korzeni okazał się zgubną regresją w czasy przednowoczesne, doprowadził Niemcy do upadku moralnego i kulturalnego, okazał się fatalną alternatywą dla doświadczeń kontyngencji moderny. Zamierzony powrót do stałych i sprawdzonych wartości, którymi ogłoszono: ojczyznę (Vaterland), naród (Volk), tradycyjną rodzinę, porządek patriarchalny i antyfeministyczny, doprowadził do największej katastrofy XX wieku.

Większość autorów tego kierunku, na przykład Wolfgang Borchert (19211947), Heinrich Böll (1917-1985), Arno Schmidt (1914-1979), to powracający z wojny żołnierze próbujący przedstawić realistyczny obraz przeżyć wojennych oraz poszukujący odpowiedzi na pytania, jak mogą odnaleźć się w powojennej rzeczywistości, w uzyskanej wolności. By zerwać z bolesną przeszłością, postulowali teorię wytrzebienia oraz negację wszelkich utartych szablonów myślowych i językowych.

Zadekretowane przez nazistów prawo do zniewolenia człowieka, z glajchszaltowania w neofeudalnym, przestępczym systemie, pozostawiło po sobie ślady, które doprowadziły w latach sześćdziesiątych do zastąpienia modernizmu postmodernizmem, rozumianym jako „modernizacja refleksyjna” (Ulrich Beck, Anthony Giddens). Przejściu od czasów nazistowskiego zniewolenia do demokratycznej wolności, do postmoderny, towarzyszył przełomowy traktat filozoficzny Theodora W. Adorno (1903-1969) i Maxa Horkheimera (1895-1973) Dialektyka oświecenia, 1994 (Dialektik der Aufklärung, 1947), który zaskakuje radykalizmem i wskazuje nowe perspektywy intelektualne. Do tego traktatu w swoich poglądach odnosili się Zygmunt Bauman, Michel Foucault i Jean-François Lyotarda. Zamieszczone tam szkice filozoficzne są bezkompromisową analizą konsekwencji tendencji modernistycznych i rozwoju kultury masowej. Sztuka i literatura otwierają przestrzenie wolności, wzmacniają myślenie refleksyjne: „Dzieło sztuki, podobnie jak magia, tworzy własny, samodzielny obszar, oddzielony od powszechnego myślenia, rządzący się własnymi prawami”.

W 1947 roku pisarz i publicysta H.W. Richter zgromadził wokół siebie nieformalne środowisko ludzi literatury: pisarzy, krytyków literackich, wydawców, tak zwaną Grupę 47. Do 1967 roku, kiedy grupa spotkała się po raz ostatni, zapraszani na spotkania pisarze tworzyli klimat literacki w Niemczech. Początków Grupy 47 należy doszukiwać się w jej pracach publicystycznych, które oscylowały między poszukiwaniem nowej stabilizacji a zakłócaniem status quo, między normalizacją 
a nonkonformizmem w sferze literacko-estetycznych i politycznych dyskursów wczesnej RFN. Autorzy tacy jak Günter Grass (1927-2015) czy Alfred Andersch (1914-1980) wnosili swoimi tekstami literackimi czy odezwami ton irytacji do dyskursów społecznych, zajmowali krytyczne stanowisko wobec zmian zachodzących w polityce wewnętrznej i międzynarodowej. W tym kontekście należy też umieścić ich próby utrzymania dialogu z autorami i ludźmi kultury z NRD i innych krajów bloku wschodniego. Dziś coraz bardziej dochodzi jednak do głosu opinia, że autorów Grupy 47 można postrzegać jako czynnik stabilizujący system zachodnioniemieckiej historii mentalnej. Dwie pierwsze generacje autorów powojennych tworzyły wprawdzie teksty krytyczne wobec teraźniejszości, jednakże niewnoszące znaczącego wkładu w przepracowanie nazistowskiej przeszłości - przeciwnie, przeważały raczej apologetyczne niż krytyczne wzorce podejścia do niej. W swoich wczesnych tekstach Richter, Andersch, Schnurre, Eich czy Walter Kolbenhoff (1908-1993) odwoływali się do wspólnego jądra doświadczeń wojny i niewoli, realizując w ten sposób program literacki tragicznych ofiar tego czasu. Lata sześćdziesiąte XX wieku przyniosły intensywne debaty na temat niemieckiej winy, wojny, Holocaustu i wolności, które znalazły oddźwięk również w tekstach Grupy 47, ale nie były jej zasługą. Rozpad grupy miał z pewnością wiele wspólnego $\mathrm{z}$ silnym zaangażowaniem się $\mathrm{w}$ sprawy polityczne i estetyczne nowej generacji, tak zwanej generacji roku 1968. Matthias N. Lorenz, prowadząc przez wiele lat badania nad twórczością i wpływem politycznym członków Grupy 47, doszedł do następującego przekonania:

to, że ów starannie kultywowany własny wizerunek nie został zakłócony przez dziesięciolecia, wynika również z solidarności i wzajemnej afirmacji grupy. Grupa 47 funkcjonowała jako przykrywka, pomagająca w przemilczaniu odpowiedzi na pytania dotyczące nieprzejrzystości życiorysów członków grupy. [...] Krytyczne studia germanistyczne muszą stawić jej czoła i znaleźć odpowiedź na pytanie, co oznacza wypieranie nazistowskiej przeszłości i samoinscenizacja uprawiana przez lata przez pisarzy Grupy 47 w kontekście interpretacji ich dzieł literackich ${ }^{4}$.

Lorenz wymienia nazwiska znanych członków grupy związanych bezpośrednio bądź pośrednio w okresie III Rzeszy z nazizmem lub jego ideologią: Günter Eich, Karl Krolow, Walter Jens, Walter Höllerer.

Rewolucja studencka w symbolicznym roku 1968, poprzedzona już w roku 1962 monachijskimi zamieszkami „Schwabinger Krawalle” i ruchem studenckim zwanym opozycją pozaparlamentarną, obaliła mit Grupy 47, której członkowie z perspektywy rewolucyjnej młodzieży przynależeli do generacji rodziców, posiadającej doświadczenie wojenne i nierzadko współwinnej działaniom nazistowskim. Ruch pokolenia 68 to ruch na wskroś wolnościowy - Bazon Brock określa je jako najbardziej skuteczne pokolenie od zarania czasów 5 . Owo pokolenie, niezależnie od narodowości, domagało się radykalnego upadku amerykańskiej supremacji, zwy-

${ }^{4}$ M.N. Lorenz, „Notwendige Neubewertung”, Tageszeitung junge Welt, 6.09.2016, https://www. jungewelt.de/artikel/317705.notwendige-neubewertung.html.

${ }^{5}$ B. Brock, Lust - Marsch durchs Theoriegelände. Musealisiert Euch!, Köln 2008, s. 32. 
cięstwa Rosji w konflikcie Wschód-Zachód, zwycięstwa maoistów w wojnie kultur przeciwko konserwatystom, uwolnienia Trzeciego Świata, zwycięstwa Afrykańczyków nad białym rasizmem, a także równouprawnienia kobiet. Tak wyglądały lista życzeń i cele pokolenia 68, wyraźnie nawiązujące do imperatywu kategorycznego Kanta; chodzi w nich o silny związek wolności, rozumu i moralności. Pięćdziesiąt lat później można skonstatować stan świata w następujący sposób: amerykańskie próby zawładnięcia światem nie powiodły się, Rosja oraz Chiny dominują w gospodarce i polityce świata, Trzeci Świat odkrył islam jako siłę wiążącą kraje północnej Afryki, problem walki $z$ rasizmem stał się tematem politycznym, społecznym i kulturalnym, a debata \#MeToo jest kolejnym krokiem w dyskusji o prawa człowieka w ogóle. To triumf generacji 68, mimo że w zasadzie nie miała ona większego wpływu na taki rozwój sytuacji - wszelkie zmiany dokonały się za sprawą globalizacji, czyli procesów prowadzących do współzależności systemów gospodarczych, społeczeństw, kultur oraz skurczenia się przestrzeni społecznych.

Uwe Timm postrzega ruch 68 bardzo pozytywnie; widzi w nim proces demokratyzacji społeczeństwa u podstaw. Szczególnie we Francji i w Niemczech bunt studentów doprowadził do bardzo ważnych zmian w kontekście obyczajowości, wolności i prawa w zachodnich społeczeństwach. W redakcjach gazet, teatrach, na uniwersytetach wymuszony został współudział całej społeczności przy podejmowaniu decyzji. W tym czasie rozpoczął się proces odchodzenia od powojennej Europy i powojennego porządku świata, który zdominowany był poprzez stare struktury, hamujące rozwój człowieka i swobody obywatelskie.

W 1965 roku H.M. Enzensberger powołał do życia pismo „Kursbuch”, którego naczelnym zadaniem było krytyczne przedstawianie wydarzeń życia kulturalnego i literackiego. Poddawał ocenie ograniczoną świadomość literacką, ignorującą szerokie obszary rzeczywistości społecznej i politycznej. Zadane w „Kursbuch 15” pytanie Enzensbergera o śmierć literatury, rozumiane jako metafora zerwania z grobową merytoryką, metafizyką i eskapizmem na korzyść tematyki społecznej, znalazło szeroki oddźwięk w świecie literackim. Odpowiedzią Martina Walsera (ur. 1927) było proklamowanie haseł nawołujących literatów do zajęcia się tematami politycznymi i wprowadzenia ich do tekstów literackich. Enzensberger już w 1960 roku w eseju Poezja i polityka opowiedział się za polityzacją literatury jako bezpośrednią reakcją na aktualne wydarzenia, nieprawidłowości i skandale. Odrzucał literacki patos liryki powojennej, głosił koniec literatury nieprzydatnej w walce społeczno-politycznej, tworzył poezję rzeczową, lakoniczną, zorientowaną na codzienność. W eseju Gemeinplätze, die Neueste Literatur betreffend, 1968 [Banały dotyczące najnowszej literatury], postawił tezę, że powojenna literatura niemiecka trwa w permanentnej agonii, uchodzi za substytut życia społeczno-politycznego i jest bezużyteczna. Swój program poetycki Enzensberger przedstawił w znanym wierszu do wypisów dla wyższej klasy licealnej (ins lesebuch für die oberstufe, wyd. pol. 2001) ze swego pierwszego zbioru poezji verteidigung der wölfe, 1957 [obrona wilków]. Słowa podmiotu lirycznego skierowane do młodego człowieka (syna) pełnią funkcję użytkową: 
ostrzegają przed zagrożeniami współczesnego świata, wytrącają z letargu, zmuszają do przemyśleń, zajęcia stanowiska i działania w imię indywidualnej i społecznej wolności. W apelu „nie czytaj ód [...], czytaj rozkłady jazdy” liryczne ja przeciwstawia się tendencjom eskapistycznym i przekonuje o potrzebie nieustannej czujności i zaangażowania, „żeby w płuca władzy dmuchać / drobny śmiercionośny pył”. Poeta jest według Enzensbergera „kronikarzem niepokoju”: za pomocą słów powinien stawiać opór przemocy i zniewoleniu.

Generacja 68 odnosi się krytycznie do zjawisk kontynuacji konserwatywnego porządku elit zarówno na uniwersytetach, w sądownictwie, administracji, jak i często w szkolnej edukacji, dezaprobuje globalne wydarzenia, przede wszystkim wojnę w Wietnamie. Podczas manifestacji 2 czerwca 1967 roku przeciwko wizycie szacha Persji Mohammada Rezy Pahlawiego w Berlinie Zachodnim zastrzelony został Benno Ohnesorg (1940-1967), co doprowadziło do gwałtownych protestów studenckich. Śmierć Ohnesorga spowodowała radykalizację niemieckiej młodzieży, a jej następstwem było utworzenie skrajnie lewicowej, anarchistycznej organizacji terrorystycznej pod nazwą Ruch 2 Czerwca.

Działania pokolenia 68 zainspirowały wielu ludzi teatru, filmu i literatury do przeniesienia realnych zdarzeń w świat fikcji literackiej. W roku 2005 Uwe Timm (ur. 1940) opublikował opowiadanie Der Freund und der Fremde [Przyjaciel i nieznajomy], w którym poddaje fikcjonalizacji przyjaźń z Benno Ohnesorgiem. Podobnie też we wcześniejszych tekstach Timm sięga po motywy rewolty studenckiej jako wyrazu walki o wolność i demokrację, o prawo do samostanowienia, o federalizację życia społecznego i politycznego Niemiec. Utwór Heißer Sommer z roku 1974 [Gorące lato] wraz z tekstami Kerbels Flucht, 1980 [Ucieczka Kerbelsa] i Rot, 2001 [Czerwony] tworzy Trylogię 68, w której Uwe Timm wskazuje na przemiany generacyjne na tle historii Federalnych Niemiec. Timm pisze powieści, w których rozważa problemy współczesności, zadając wciąż pytanie o możliwość indywidualnej wolności w zastanych ramach społecznych.

Rok 1968 to czas przełomu w myśli humanistycznej: Leslie A. Fiedler, amerykański literaturoznawca, wygłasza wykład na Uniwersytecie we Fryburgu Bryzgowijskim, zatytułowany The Case for Post-Modernism (Cross the Border - Close the Gap, opublikowany w „Playboyu”!), w którym wskazał, że podział na kulturę elitarną i masową jest przestarzały. W 1979 Jean-François Lyotard w tekście Kondycja ponowoczesna: raport o stanie wiedzy (La condition postmoderne) ogłosił upadek „,wielkich metanarracji oświeceniowych": wyzwolenia racjonalnego podmiotu i historii jako rozumnego postępu. Kiedy jeszcze klasyczny podmiot mieszczańskiego ideału, który zainteresowany zdobywaniem społecznego statusu i sukcesem, musiał rezygnować na rzecz obowiązków i konwencji ze swoich właściwych życzeń i potrzeb, a romantyczny podmiot wprawdzie eksperymentował w poszukiwaniu siebie, ale płacił za to życiem na marginesie społeczeństwa, to ponowoczesny subiekt żąda od życia jednego i drugiego: chce się sam rozwijać, być społecznie uznany i odnieść sukces, walczy z wszelkimi przejawami konformizmu społecznego i niebezpiecznych 
monopolizacji ${ }^{6}$. Ta forma wolności zbliża się do postulatów głoszonych w filozofii Johna Stuarta Milla (1806-1873).

Rok 1968, podobnie jak 1979, 1990, 2001, należy uznać za moment kluczowy dla stopniowych zmian paradygmatów zarówno politycznych, jak społecznych, kulturowych i literackich w kierunku od zorganizowanej nowoczesności ku ponowoczesności, ku postmodernie i powstaniu fenomenu jednostkowości, jak określa to Rekwitz. Literackie zmiany paradygmatów mają charakter długoterminowy, fundamentalny i są konkretyzowane na znamiennych wydarzeniach, które same wywołują zmiany strukturalne i jednocześnie mają historyczny wymiar symboliczny. Ruch protestacyjny lat 1968 należy rozumieć jako wyraz „kultury rewolucyjnej”, kontrkultury (counterculture), która była decydującym impulsem do postmaterialistycznej przemiany wartości: $\mathrm{z}$ wartości obowiązkowych i afirmatywnych w kierunku wartości samorealizacji. Tym samym były one impulsem do rozwoju lewicowego liberalizmu następnych dziesięcioleci, opierającego się na hasłach podniesienia jakości życia, indywidualnego samostanowienia i różnorodności kulturowej. Samotna samorealizacja kontrkultur poruszała się najpierw w subkulturowych niszach i była skierowana przeciwko „systemowi” społeczeństwa większości i przeciwko jego wyobcowującym mieszczańskim praktykom. Jednocześnie owo „ja” należy rozumieć jako przedmiot ekstensywnej samoeksploracji, podczas której rozpoznawane i odkrywane zostały prawdziwe, autentyczne pragnienia ${ }^{7}$. Kultura protestu doprowadziła do powstania i aktywnego rozwoju ruchów feministycznych, ekologicznych, ruchu homoseksualnego, Amnesty International czy ruchów pacyfistycznych, które miały równie istotne znaczenie dla poetyki tekstów literackich tego okresu. W roku 1978 Uwe Timm wydał Morengę - powieść polityczną, powstałą we współpracy z grupami silnie zaangażowanymi w sprawy Trzeciego Świata i ruch sprzeciwu wobec apartheidu. Tytułowa figura powieści to bojownik o wolność, który próbuje zapobiec ludobójstwu w Niemieckiej Afryce Południowo-Zachodniej, dzisiejszej Namibii. Gdy ukazała się Morenga, przeszłość kolonialna Niemiec nie była tematem społecznym; Uwe Timm twierdzi nawet, że w tym czasie Niemcy uważani byli za dobrych kolonizatorów, a on sam został oskarżony o szkalowanie dobrego imienia narodu ${ }^{8}$. Polityczne pisarstwo to znalezienie literackiej formy samokrytyki, która ukazałaby wypaczenia, zmuszałaby do refleksji i zadawałaby krytyczne pytania o status quo. Timm jest więc pisarzem politycznym w sposobie, w którym fikcyjnie przedstawia rzeczywistość: osiąga swoje cele poprzez właściwe prowadzenie narracji, na przykład o cielesnych karach dokonywanych na Afrykańczykach, oraz wykorzystywanie cytatów z korespondencji między urzędem kolonizacyjnym a stacjami kolonizatorów. W takich miejscach Timm rezygnuje z fikcjonalizacji na rzecz wprowadzenia dokumentów czasu.

Lata sześćdziesiąte i siedemdziesiąte charakteryzują się zatraceniem wiary w realistyczną powieść mieszczańskiej proweniencji: podejrzewana o wspieranie ist-

6 A. Reckwitz, Die Gesellschaft der Singularitäten, Berlin 2019, s. 289.

7 Ibidem, s. 291.

8 U. Timm, R. Hebeck, I. Mangold, „Die Zeit-Gespräch”, Die Zeit 2020, nr 14. 
niejących konserwatywnych, restauracyjnych struktur, powinna zostać zastąpiona innymi, bardziej produktywnymi formami. Skutkiem tych ruchów było powstanie literatury różnorodnej, mieszającej fakty z fikcją — koniunkturę zdobyła literatura dokumentalna podejmująca często tematy krytyczne społecznie, jak na przykład twórczość Güntera Wallraffa (ur. 1942) Na akord, 1974 (Wir brauchen dich, 1966), czy Eriki Runge (ur. 1939) Erna E., gospodyni domowa, 1974 (Hausfrau Erna E., 1968) z tomu Bottroper Protokolle, 1968 [Protokoły z Bottrop] i Frauen, 1969 [Kobiety].

Rok 1979 to moment rozpoczynający falę zwycięstw politycznego neoliberalizmu, który wkrótce podporządkuje politykę gospodarczą i społeczną radykalnej, zderegulowanej strukturze rynku i konkurencji. Jest to początek globalnej polityki promującej konkurencyjne państwo zorientowane na innowacje. Dla generacji lat osiemdziesiątych poszukiwanie doświadczeń i przeżyć nie jest już domeną subkultur, ale ukierunkowuje się na bogatą ofertę kulturalną, turystyczną globalnego świata.

Rosnące rozluźnienie związków międzyludzkich zarówno w obszarze pracy zawodowej, jak i w konstelacjach rodzinnych tworzy nowe formy wolnościowe, które jawią się w kontekście przyczynowo-skutkowym dobrobytu, mobilności i zmiennych związków socjalnych. Owa „modernizacja refleksyjna” inspiruje do tworzenia literatury refleksyjnej, która poddaje dyskusji własne założenia poetologiczne.

Przemiany społeczne zapoczątkowane rewoltą studencką rozbudziły ruch feministyczny, a przybierająca na sile emancypacja kobiet oferowała nowe poczucie wolności oraz rozluźnienie związków rodzinnych i zawodowych. W 1975 roku ukazała się powieść mieszkającej od 1967 roku w Berlinie szwajcarskiej autorki Vereny Stefan (1947-2017) Häutungen [Linienie], która stała się manifestem ruchów kobiecych i przedmiotem analiz na seminariach germanistycznych. Głównymi impulsami do napisania tej zabarwionej autobiograficznie powieści były z jednej strony rewolucja seksualna, antykoncepcja i zmiany dokonujące się w relacjach między płciami, z drugiej niezmienny status kobiety jako obiektu męskiego pożądania seksualnego.

Przełom dokonany za sprawą pokolenia 68 miał w literaturze charakter modernizacyjny. Wątki polityczne odgrywały w niej odtąd coraz mniejszą rolę. Peter Schneider (ur. 1940), autor głośnego opowiadania Lenz (1973) i przedstawiciel ruchu nowej subiektywności, przyznał w 1976 roku w Literaturmagazin, że najbardziej ekscytujące teksty tego czasu stworzyli artyści, którzy twierdzili, że polityka nie jest dla nich tematem literackim. Był zdania, że wywoływanie buntu literackiego i jednocześnie politycznego nie jest możliwe. W 1978 roku Enzensberger opublikował wiersz Untergang der Titanic [Zatonięcie Titanica], uważany za pożegnanie postulatów polityzacji literatury, wnoszonych przez pokolenie 68, i za kulminację autorefleksji po 1968 roku. Podobnie inni autorzy: Friedrich Christian Delius (ur. 1943) w Amerikahaus oder Der Tanz der Frauen, 1997 [Amerykański dom albo Taniec kobiet], Uwe Timm w Heißer Sommer, 1976, czy Bernd Caillo (ur. 1945) w Das Geschäftsjahr 1968/69, 2005 [Rok gospodarczy 1968/69] podsumowali własną rolę w ruchu pokolenia 68 i podjęli próbę umieszczenia swych doświadczeń i przeżyć na osi historycznej rozwoju RFN. Gorace lato Uwego Timma należy do najważniejszych 
utworów fikcjonalizujących rewolucję studencką 68 . W powieści przedstawione są procesy wolnościowe młodej generacji, walczącej o wyzwolenie z więzów konserwatywnej władzy generacji starszej.

Książką kultową tego okresu stał się esej powieściowy Die Reise [Podróż] Bernwarda Vespera (1938-1971), wydany pośmiertnie w 1977 roku. Podróż można odczytać jako dokument szaleństwa, odurzenia narkotycznego, rozprawy z niemocą i bezsilnością, jako zwierciadło zbiorowej porażki całego pokolenia, które w latach sześćdziesiątych zamierzało zmienić skamieniałe społeczeństwo.

Wiersz jako moment wolności - taki tytuł nadaje Hilde Domin (1909-2006) jej frankfurckim wykładom poetologicznym w semestrze zimowym 1987/88. Wyjaśnia to w następujący sposób: „[...] Erreichen dieses Zustands, und wenn er da ist, dann hörtalles andere auf. Vor allem die Zeit. Aber auch das Rollenmenschendasein" („Jest to osiągnięcie takiego stanu, w którym wszystko inne przestaje istnieć. Przede wszystkim czas. Ale także istnienie jako człowiek w przypisanej mu roli”) ${ }^{9}$. Taka forma egzystencji możliwa jest jedynie wówczas, kiedy jednostka pojmowana jest jako subiekt, a nie obiekt, w momencie absolutnego samostanowienia.

W 1979 roku byli redaktorzy magazynu „Pardon”, pisarze, graficy i rysownicy, przedstawiciele tak zwanej nowej szkoły frankfurckiej: Robert Gernhardt (19372006), Peter Knorr (ur. 1939), Hans Traxler (ur. 1929) i Chlodwig Poth (1930-2004), założyli we Frankfurcie nad Menem magazyn satyryczny „Titanic”, który ustosunkowując się krytycznie do rzeczywistości, ośmieszając i piętnując zjawiska społeczne i polityczne, do dzisiaj wpływa na niemiecką opinię publiczną.

Wydarzenia z roku 1990 miały ogromne symboliczne oddziaływanie. Upadek ustroju socjalistycznego w Związku Radzieckim oraz krajach Europy Wschodniej i Środkowej oznaczał koniec siedemdziesięcioletniego eksperymentu społecznego, polegającego na kompleksowej regulacji wszystkich procesów społecznych w imię ideału równości. Ta skrajna wersja „polityki ogółu” zostaje zastąpiona globalnym zniesieniem granic procesów gospodarczych i kulturowych.

Lata dziewięćdziesiąte to czas poważnych przemian wewnątrz społeczeństwa niemieckiego. Zjednoczenie Niemiec uświadomiło obywatelom obu krajów, jak bardzo się od siebie różnią. Miało to bezpośrednie przełożenie na różnice w twórczości literackiej autorów z byłej NRD, którzy opracowywali literacko własną historię i nową rzeczywistość, mówią o rzeczywistości NRD i jej upadku, o relacjach niemiecko-niemieckich, o doświadczeniu nowej wolności oraz autorów krajów zachodnich, których tematyka dotyczyła raczej indywidualizacji i globalizacji społeczeństw. Z głównych tekstów autorów NRD tego okresu warto wyliczyć następujące: Thomasa Rosenlöchera (ur. 1947) Die verkauften Pflastersteine, 1990 [Sprzedane płyty chodnikowe], Thomasa Brussiga (ur. 1964) Aleja słoneczna, 2002 (Am kürzeren Ende der Sonnenallee, 1999), Helden wie wir, 1995 [Bohaterowie jak my], Jensa Sparschuha (ur. 1955)

${ }^{9}$ H. Domin, Das Gedicht als Augenblick von Freiheit. Frankfurter Poetik-Vorlesungen (1987/88), München-Zürich 1988, s. 8. 
Der Zimmerspringbrunnen, 1995 [Fontanna pokojowa], Ericha Loesta (1926-2013) Kościół św. Mikołaja 1997 (Nikolaikirche, 1995), Ingo Schulzego (ur. 1962) Simple Storys, 1998 [Proste historie], czy Uwe Tellkampa (ur. 1968) Der Turm, 2008 [Wieża]. Charakterystycznym elementem tych testów niemoc mówienia o upadku NRD i procesach zjednoczeniowych, ujawniająca się w ich fragmentaryczności, parabolice, nasyceniu elementami satyry. Od połowy lat dziewięćdziesiątych pojawiają się utwory nieco bardziej wyważone, pozbawione emocji i osądzania przeszłości. Tak jak na literaturę wschodnią oddziaływała nowa sytuacja polityczna, tak na literaturę zachodnią miała wpływ nowa sytuacja społeczna świata Zachodu w ogóle ${ }^{10}$. Habeck w wywiadzie dla „Die Zeit” konstatuje: „długo wierzyliśmy, że zmiany, dokonane przez ruch 68 będą kontynuowane po 1989, w sensie ruchu wolnościowego i liberalizacyjnego, prowadzącego do europejskiego triumfu społeczeństwa liberalnego". Założenie to, i tutaj są Habeck i Timm zgodni, okazało się błędne - najpóźniej w czasie kryzysu finansowego w latach 2008/2009, później podczas kryzysu migracyjnego w 2015 roku, a swojej kulminacji doznało w 2020 podczas pandemii wirusa korony.

Najgłośniejszym echem w literaturze starych landów odbiła się myśl o globalizacji, połączeniu świata internetem, komercjalizacji życia, o kulturze masowej i świecie konsumpcji. $Z$ tego doświadczenia powstała w latach dziewięćdziesiątych i tu nowa literatura, nowa nie tyle w tematach, ile w wyrazie, można ją określić jako lekką, bawiącą, beztroską i przede wszystkim wolną od ideologii i ciężaru przeszłości. Zadziwia kalejdoskop tematyczny, ku któremu zwrócili się młodzi autorzy. W 1995 roku szwajcarski autor Christian Kracht (ur. 1966) opublikował powieść Faserland, dając nią początek drugiej fazie kultury pop. Podobnie jak podczas pierwszej fazy w latach sześćdziesiątych i siedemdziesiątych też literatura pop lat dziewięćdziesiątych czerpała inspiracje z kultury anglojęzycznej. Benjamin von Stuckrad-Barre (ur. 1975), pisząc powieść Soloalbum, 1998 [Album solo], zainspirował się powieścią High Fidelity, 1995 [Wierność w stereo], Nicka Hornby’ego (ur. 1957). Do istotnych i chętnie czytanych w latach dziewięćdziesiątych tekstów literatury pop należą powieści Alexy Hennig von Lange (ur. 1973), na przykład Relax, 1997 i Ich habe einfach Glück, 2001 [Mam po prostu szczęście], tomy opowiadań Judith Hermann (ur. 1970) Letni dom, później, 2004 (Sommerhaus, später, 1998), Nichts als Gespenster, 2003 [Tylko duchy], w których opowiadane są historie o niespełnieniu, niewykorzystanej szansie życiowej, oczekiwaniu i poszukiwaniu, a figury cechuje beztroska, niefrasobliwość, bezsilność i bierność. Niemieckojęzyczna literatura pop znajduje się w sferach silnych wpływów „kondycji ponowoczesnej”"11, kluczowych formuł tożsamości postmodernistycznych, którymi była wielokulturowość i pluralizm. Lyotard wyróżnia i odrzuca wielką narrację wolności, posługującą się figurą ludu zrzucającego z siebie pęta tyranii świeckiej i religijnej, by zyskać powszechne prawo do wiedzy (edukacja powszechna) i prawo do władzy (demokracja). Narzędziem jest tu rewolucja eman-

10 Więcej na ten temat zob. M. Wolting, „Życie literackie w zjednoczonych Niemczech”, Przegląd Zachodni 66, 2010, nr 2, s. 37-44, tu: s. 40-41.

11 J.F. Lyotard, La Condition postmoderne: rapport sur le savoir, Paryż 1979.

Miscellanea Posttotalitariana Wratislaviensia 8, 2020

(C) for this edition by CNS 
cypująca metafizycznie pojmowany lud. Postmoderne indywiduum samo decyduje o tym, jaki chce realizować życiorys. To doświadczenie staje się tematem wielu utworów literackich, gdyż często protagonistów przerasta możliwość versus konieczność dokonywania ciągłych wyborów i określania siebie wciąż na nowo. Protagoniści Krachta, pochodzący zazwyczaj z bogatych rodzin, zmagają się z trudnościami zawierania związków międzyludzkich. Definiują się przede wszystkim poprzez ubrania i produkty markowe. W czasach dezorientacji określenia nazistowskie używane są bez obciążeń. Pierwszoosobowy narrator nie jest jednostką wolną, ucieka wciąż od odpowiedzialności za siebie i za innych, jest napędzany tylko własnymi potrzebami.

W latach dziewięćdziesiątych do głosu doszła nowa generacja pisarzy, ludzi młodych, nieskażonych indoktrynacją polityczną, nienoszących doświadczenia wojny w bagażu, niehołdujących wierze w idealizm, romantyzm uzdrawiający świat. Cechą dla nich wspólną była chęć tworzenia wizerunku literatury niemieckiej, byli literatami aktywnymi medialnie i płodnymi twórczo - choć obie te wartości mogą być produktem polityki wydawniczej nowego państwa niemieckiego, „FAZ” pisała już w 1990, „Die Zeit” w 1994, a „Der Spiegel” w 1995 o „drugiej godzinie zero” dla literatury niemieckiej. Felietoniści i krytycy literaccy prognozowali wytworzenie się nowej jakości literatury niemieckiej, była mowa o zwrocie ku opowiadaniu, zwłaszcza w duchu tradycji amerykańskiej. Powstająca literatura pop była literaturą czytelną i zrozumiałą dla szerszej społeczności, zdradzała tendencje do „opowiadania bez skrupułów", bez strachu przed stereotypami i kiczem, pisarze pisali bez obciążeń, ograniczeń i zobowiązań tak moralnych, jak i politycznych. Podejmowanie tematów bezpośrednio związanych z polem przeżyć osobistych człowieka to próba ucieczki literatów do prywatności związków międzyludzkich. Kiedy indywiduum nie widzi dla siebie miejsca na scenie społecznej, gospodarczej czy politycznej, zaczyna poszukiwać jakiegoś surogatu, który mógłby kontrolować. Opowiadania Elke Naters (ur. 1963) Königinnen, 1998, Lügen, 1999 [Królewny i Kłamstwa], Julii Franck (ur. 1970) Liebediener, 1999 [Słudzy miłości], Davida Wagnera (ur. 1971) Meine Nachtblauehose, 2000 [Moje niebieskie spodnie] traktowały o dystansie i bliskości, zaufaniu i obcości, strachu, stracie, pożądaniu, zazdrości, nienawiści, samotności, wstydzie, izolacji, wolności, przyjaźni i wciąż o miłości.

Rok 2001, z terrorystycznym atakiem na World Trade Center w Nowym Jorku to kolejny zwrot w pojęciu neoliberalnej wolności. W dacie 11 września skupia się radykalizacja religijno-islamskiego fundamentalizmu oraz pozycjonowanie się Zachodu, wyrażane nierzadko pojęciem „walka kultur”. W wyniku ataków terrorystycznych, kryzysu bankowego, powrotu do myśli narodowościowych, nowych wojen, fal migracyjnych, kryzysu migracyjnego w 2015 roku katastrofy klimatycznej w miejsce optymizmu postępu, modernizacji życia lat pozjednoczeniowych wkroczyły rozczarowanie i niemoc. Protagoniści współczesnych tekstów literackich, na przykład dramatów Falka Richtera Trust, Never Vorever, Nacht um halb zwei, przekonani o swojej wyjątkowości i jednostkowości, się rozczarowują. Alain Ehrenberg, francuski filo- 
zof, postawił diagnozę o „zmęczonym/wyczerpanym ja” ${ }^{12}$. Konsekwencjami takiego sposobu życia protagonistów jest wiele negatywnych emocji, jak wypalenie, ogólna frustracja, strach, stawianie nadmiernych wymagań, których w pozytywnej kulturze emocjonalnej nie powinno być i które są wynikiem samooptymalizacji i performancji autentyczności. Falk Richter tworzy teatr polityczny, który zawsze odnosi się do społeczeństwa, zajmuje stanowisko w sprawie związków władzy ze społeczeństwem i zajmuje się sprawami ważnymi i naglącymi społecznie. Richter kreuje swoimi sztukami możliwości innego życia, innej wspólnoty, gdyż przedstawiona różnica w stosunku do przyjętej normy jest materiałem, z którego powstają historie teatralne. Świat przedstawiony w Never Vorever i Trust pokazuje, jak daleki jest on od oczekiwanego świata liberalizmu, wolności, autonomii i samoodpowiedzialności. Świat protagonistów pełen jest ograniczeń, restrykcji, grozi mu antyliberalna restauracja.

\section{Bibliografia}

Brock, Bazon. 2008. Lust — Marsch durchs Theoriegelände. Musealisiert Euch!. Köln: Dumont.

Domin, Hilde. 1988. Das Gedicht als Augenblick von Freiheit. Frankfurter Poetik-Vorlesungen (1987/88). München-Zürich: Piper.

Ehrenberg, Alain. 2004. Das erschöpfte Selbst - Depression und Gesellschaft in der Gegenwart. Frankfurt: Campus Verlag.

Kant, Immanuel. 1972. Krytyka praktycznego rozumu. Przeł. Jerzy Gałecki. Warszawa: PWN.

Lorenz, Matthias N. 2016. „Notwendige Neubewertung”, Tageszeitung junge Welt, 6 września, https:// www.jungewelt.de/artikel/317705.notwendige-neubewertung.html.

Lyotard, Jean-François. 1979. La Condition postmoderne: rapport sur le savoir. Paryż: Minuit.

Reckwitz, Andreas. 2019. Die Gesellschaft der Singularitäten. Berlin: Suhrkamp.

Schiller, Friedrich. 1981. „Über die ästhetische Erziehung des Menschen in einer Reihe von Briefen”. W: Sämtliche Werke, t. 5. Erzählungen. Theoretische Schriften, 570-669. Darmstadt: Wiss. Buchgesellschaft.

Sparschuh, Jens. 1995. Der Zimmerspringbrunnen. Köln: KiWi.

Spinoza, Baruch de. 1961. „List LVIII — Spinoza do Schullera” [październik 1674]. W: Listy mężów uczonych do Benedykta de Spinozy oraz odpowiedzi autora wielce pomocne dla wyjaśnienia jego dzieł. Warszawa: Wydawnictwo Naukowe PWN.

Timm, Uwe, Robert Hebeck, Ijoma Mangold. 2020. „Die Zeit-Gespräch”, Die Zeit 14.

Przyjęto do druku/Accepted for publication: 30.09.2020.

12 A. Ehrenberg, Das erschöpfte Selbst - Depression und Gesellschaft in der Gegenwart, Frankfurt 2004.

Miscellanea Posttotalitariana Wratislaviensia 8, 2020

(C) for this edition by CNS 